\title{
GUILLAIN-BARRÉ SYNDROME IN THE COURSE OF DENGUE
}

\section{Case report}

\author{
Nilse Querino Santos ${ }^{1,2}$, Ana Cláudia B. Azoubel'2, \\ Antonio Alberto Lopes ${ }^{3}$, Gersonita Costa ${ }^{4}$, Aroldo Bacellar ${ }^{5}$
}

\begin{abstract}
This case report describes the findings of a 45-year-old white woman from Brazil, who developed myalgia, fever and macular rash. She was diagnosed as having dengue, based on clinical manifestations and specific IgM titers. One week after the first symptoms of dengue, the patient developed muscle weakness, followed by tetraplegia with areflexia, and respiratory insufficiency. The electromyography had evidence of demyelinating neuropathy and the cerebrospinal fluid showed albuminocytologic dissociation. These neurologic findings were consistent with the diagnosis of Guillain-Barré syndrome. The patient was treated with immunoglobulin and metylprednisolone. Mechanical ventilation was started one week after hospital admission and maintained for four weeks. After six weeks of hospitalization the patient was discharged from the hospital on wheel chair, presenting mild muscle weakness and loss of patellar and ankle reflexes. When the patient was seen at the outpatient service three weeks after hospital discharge she was able to walk with help. This case report suggests a possible association between dengue and Guillain-Barré syndrome.
\end{abstract}

KEY WORDS: Guillain-Barré syndrome, dengue, radiculoneuritis.

\section{Síndrome de Guillain-Barré no curso de dengue: relato de caso}

RESUMO - Este relato de caso descreve os achados de uma mulher de 45 anos, branca, que desenvolveu mialgia, febre e eritema macular. Ela recebeu o diagnóstico de dengue, tomando por base os achados clínicos e títulos específicos de IgM. Uma semana depois do início dos primeiros sintomas de dengue, a paciente desenvolveu fraqueza muscular, tetraplegia e insuficiência respiratória. A eletromiografia mostrou evidência de uma neuropatia desmielinizante e o liquor apresentou quadro de dissociação albuminocitológica. Os achados neurológicos foram consistentes com o diagnóstico de síndrome de Guillain-Barré. A paciente foi tratada com imunoglobulina e metilprednisolona. Ventilação mecânica foi iniciada uma semana após a admissão hospitalar, sendo mantida por quatro semanas. Após seis semanas de internamento a paciente teve alta em cadeira de rodas, apresentando fraqueza muscular e perda dos reflexos patelar e aquileu. Quando a paciente foi vista no ambulatório, três semanas após a alta hospitalar, ela já era capaz de andar com ajuda do acompanhante. Este relato de caso sugere uma possível associação entre dengue e síndrome de Guillain-Barré.

PALAVRAS-CHAVE: síndrome de Guillain-Barré, dengue, radiculoneurite.

Guillain-Barré syndrome frequently develops after an infection, including viral disease ${ }^{1}$. Cytomegalovirus, Epstein-Barr and HIV are some of the viral agents that have been associated with this neurologic syndrome ${ }^{2,3}$. Three previous reports have called attention to a possible relationship between dengue and Guillain-Barré syndrome. The mechanisms that link the infections with Guillain-Barré syndrome are not well known. There is evidence, however, that this neurologic disease is immunologically mediated ${ }^{1}$. The objective of this report is to describe the findings of a woman who developed Guillain-Barré syndrome in the course of dengue. The ethical committee of the São Rafael Hospital, where the patient was hospitalized, approved the publication.

\footnotetext{
Estudo conduzido no Hospital São Rafael, (HRD) Salvador BA, Brasil: 'Professora Adjunta, Departamento de Microbiologia, Universidade Federal da Bahia (UFBA); ${ }^{2}$ Médica do Serviço de Doenças Infecciosas do (HSR); ${ }^{3}$ Professor Adjunto, Livre-Docente, do Departamento de Medicina da UFBA; Médico Pesquisador do HSR; ${ }^{4}$ Médica do Serviço de Neurologia do HSR; ${ }^{5} \mathrm{Chefe}$ do Serviço de Neurologia do HSR.
}

Received 13 December 2002, received in final form 19 August 2003. Accepted 24 September 2003.

Dr. Aroldo Bacelar - Hospital São Rafael / 6ªndar ala C - Avenida São Rafael 2152 - 41256-900 Salvador BA - Brasil. E-mail: dicen@hsr.br 


\section{CASE}

A 45-year-old white woman, middle school teacher, was admitted on February $25^{\text {th }}$ of 1997 during an epidemics of dengue to the Sao Rafael Hospital, located in the city of Salvador, Northeast Brazil, with one week of generalized myalgia and fever. Four days after the initial symptoms she noticed macular rash, predominantly in lower limbs. Weakness in the lower limbs was noted twenty-four hours before hospital admission. On physical examination, the patient was alert and oriented. Neck was supple. She had severe weakness of the lower limbs and she was unable to show complete range of movement against gravity. Patellar hyporeflexia and symmetrical distal hypoesthesia were detected.

The initial laboratory workup (February/25/97) revealed: hematocrit 32\%, hemoglobin $10.6 \mathrm{~g} / \mathrm{dl}$, leucocyte count of 5100 (neutrophils $=50 \%$; eosinophils $-0.9 \%$ lymphocytes $=36.8 \%$ ), platelet count $148000 / \mathrm{mm}^{3}$, total protein $6.7 \mathrm{~g} / \mathrm{dl}$ (albumin $3.9 \mathrm{~g} / \mathrm{dl}$, globulin $2.8 \mathrm{~g} / \mathrm{dl}$ ), AST 35 units/l and ALT 51 units/l. HIV Elisa was negative. The cerebrospinal fluid (CSF) showed 4cells $/ \mathrm{mm}^{3}$ (lymphocytes $73 \%$, monocytes $27 \%$ ), protein $49 \mathrm{mg} / \mathrm{dl}$, chloride $690 \mathrm{mEq} / \mathrm{l}$, glucose $64 \mathrm{mg} / \mathrm{dl}, \mathrm{LDH} 20.2 \mathrm{UI}$. The CSF was also negative for syphilis (VDRL and hemagglutination), cysticercosis (ELISA and hemagglutination), S. mansoni (immunofluorescence), pneumococci (latex), tuberculosis (acid-fast stain), meningococci (latex), H. influenza (latex), cryptococcus, HIV (ELISA), HTLV I and HTLV II (ELISA). On February 28, three days after hospital admission, dengue-specific IgM antibody test was positive. IgM for CMV, HSV, EBV were negative. A second CSF exam was similar to the first, except for an albuminocytologic dissociation (protein $143 \mathrm{mg} / \mathrm{dl}$ and $3.7 \mathrm{cells} / \mathrm{mm}^{3}$ ). An electromyography showed slowed motor conduction velocity on several peripheral nerves of upper and lower limbs.

During follow-up she developed tetraparesis with facial diplegia and global areflexia. At the beginning of the second week the patients started a 5-day treatment with immunoglobulin $400 \mathrm{mg} / \mathrm{kg} /$ day plus methylprednisolone $500 \mathrm{mg}$. She was also on mechanical ventilation for approximately four weeks. Mechanical ventilation was started one week after hospital admission and maintained for four weeks. The patient was discharged from the hospital on wheel chair after six weeks of hospitalization, presenting mild muscle weakness and loss of patellar and ankle reflexes. Three weeks later when she was seen at the outpatient service she was able to walk with help.

\section{DISCUSSION}

The present report is not the first one to suggest an association between dengue and Guillain-Barré syndrome. According to a MEDLINE search from 1966 to present, three previous reports described Guillain-Barré syndrome in patients with dengue $e^{4-6}$. In the present case the presence of a positive dengue- specific lgM antibody test is an evidence of active infection or recently acquired disease. The neurologic manifestations, the CSF findings and the pattern of the electromyography were consistent with the diagnosis of Guillain-Barré syndrome.

It is important to observe that several infectious diseases have been reported as associated with Guillain-Barré syndrome ${ }^{2,3}$. It is believed that antibodies and products of the cellular responses trigged by the infections microorganism reacts to the ganglioside surface of component of the peripheral nerves ${ }^{4}$. The neurological symptoms usually appear when the patient is recovering from the acute phase of the infection, particularly in viral diseases. The existence of three previous reports of Guillain-Barré syndrome in patients with dengue is an additional support to an association between these diseases. In the present case and in the previous reports, the neurological manifestations appeared at least one week after the first clinical manifestations of dengue. The first report described a 46-year-old man who apparently acquired the disease during a trip to the French Polynesia, located in the south-central Pacific Ocean. The neurological manifestation of this Polynesian patient started approximately five weeks after the first manifestations of dengue ${ }^{5}$. A second case report was about a 28-year-old woman from the French Guiana ${ }^{6}$. The first symptoms were fever and headache followed by radicular pain. The diagnosis of dengue was based on seroconversion (inhibition of the agglutination test). One week after the onset of dengue, the patient became tetraplegic. She recovered without residua. The third report described the findings of a 44-year-old woman from Caribe $^{7}$. The first symptoms were fever, rash, vomiting and anorexia. These symptoms remitted in four days. Two weeks later she complained of tiredness, with numbness and weakness of both legs and arms. After 48 hours she became unable to walk. This patient also had a complete recovery.

At the time that the patient was admitted plasma exchange was not available at our hospital. The patient was treated with human intravenous immunoglobulin plus methylprednisolone based on preliminary findings that suggested this combination as an alternative to plasma exchange with the advantage of lower adverse effects and easy of application ${ }^{4}$. Moreover, at that occasion there was a suggestion that the combination of immunoglobulin with methylprednisolone was associated with better results than immunoglobulin alone in patients 
with Guillain-Barré syndrome ${ }^{8}$. There is doubt, however, if corticosteroids add any benefit for patients with Guillian-Barré syndrome ${ }^{4}$. Plasma exchange and intravenous immunoglobulin are considered equivalent in terms of efficacy in the treatment of Guillain-Barré syndrome. Moreover, there are data to suggest that the combination of the two drugs do not confer a significant advantage ${ }^{5,9}$.

Obviously, the development of Guillain-Barré syndrome in the course of dengue in the present case could have been a coincidence. However, since Guillain-Barré syndrome is a rare disease it is plausible to hypothesize that the two diseases were causally associated. Future studies to assess possible causes of Guillain-Barré syndrome should consider the possibility of dengue.

\section{REFERENCES}

1. Hughes RA, Hadden RD, Gregson NA, Smith KJ. Pathogenesis of Guillain-Barré syndrome. J Neuroimmunol 1999;100:74-97.

2. Jacobs BC, Rothbarth PH, van der Meche FG, et al. The spectrum of antecedent infections in Guillain-Barre syndromé: a case-control study. Neurology 1998;51:1110-1105.

3. Thornton CA, Latif AS, Emmanuel JC. Guillain-Barré syndrome associated with human immunodeficiency virus infection in Zimbabwe. Neurology 1991;41:812-815.

4. Hahn AF. Guillain-Barre syndrome. Lancet 1998; 352:635-641.

5. Paul C, Dupont B, Pialoux G. Polyradiculonévrite aiguë secondaire à une dengue. Presse Med 1990;19:1503.

6. Sainte Foie S, Niel L, Moreau JP, Ast R, Chippaux A. Un cas de polyradiculonévrite associé a une dengue chez une patiente originaire de la Guyane Française. Bull Soc Pathol Exot 1993;86:117-118.

7. Esack A, Teelucksingh S, Singh N. The Guillain-Barré syndrome following dengue fever. West Indian Med J 1999;48:36-37.

8. Dutch Guillain-Barré Study Group. Treatment of Guillain Barré syndrome with high-dose immune globulins combined with methylprednisolone: a pilot study. Ann Neurol 1994;35:749-752.

9. Lyu RK, Chen WH, Hsieh ST. Plasma exchange versus double filtration plasmapheresis in the treatment of Guillain-Barré syndrome. Therapeutic Apheresis 2002;6:163-166. 